\title{
THE ROYAL MOSQUES IN INDONESIA FROM 16TH TO EARLY 20TH CENTURIES AS A POWER REPRESENTATION
}

\author{
ISMAN PRATAMA NASUTION \\ Department of Archaeology, Faculty of Humanities, Universitas Indonesia, Indonesia.
}

\begin{abstract}
This study describes the characteristics of the royal mosques in Indonesia from the 16th century to the early 20th century through the architectural and archaeological study of the building's components. Royal mosques are meaningful in the concept of building because they are the places for sultans and their people to pray, and these mosques are located in the capital cities of the Islamic empires that represent the sultans and became the identity of the characters of the Islamic empires in the past. Through architectural and archaeological studies of several kingdom's mosques in Java, Sumatra, Borneo, Sulawesi and North Maluku, this research observes the data with the context of space (spatial) with the central government (the palace), squares, markets, tombs and other buildings of a king. In addition, this paper studied the aspects of power relations with the palace mosque as the centre of power, to reveal the power of representation in the mosque, with attention to the style of the building and ritual. The results obtained show that the royal mosques in Indonesia have special characteristics displayed in the building form and the local ritual practices that are different from non-royal mosques and the mosques outside of Indonesia as a strategy and resistance against global Islamic power relations in the past.
\end{abstract}

Keywords: identity and resistance, royal mosque, the representation of power.

\section{INTRODUCTION}

Ancient mosques in Indonesia have typical characteristic patterns or shapes when compared with shades of mosques in other countries. The specificity of the art style of such mosques [1] depicts the universality of the factors contained in the mosque, according to hadits (Prophet Mohammad's tradition); and there are no rules listed in the verses of the Koran on how to construct the mosque, but its direction is mentioned, which is called qibla. Thus, in the Islamic world, architects and Muslim communities have the freedom to be creative to build mosque structures. A number of mosques that show the peculiarities of the architecture of ancient mosques [2] are the Great Mosque of Demak (Demak), the Great Mosque of Banten (Serang), the Great Mosque of Kasepuhan (Cirebon), the Great Mosque of Yogyakarta (Yogyakarta), the Great Mosque of Surakarta (Surakarta), Masjid Agung Palembang (Palembang), Masjid Raya Ternate (Ternate), Masjid Raya Baiturrahman - the first Banda Aceh mosque, Aceh Indrapuri mosque, the Great Mosque of Sumenep, Angke Jakarta Mosque, and many more (Fig. 1).

The specificity of ancient mosques [2] is described as follows: (1) the schematics rectangular or square-shaped solid; (2) the storey roof consisting of two, three, five or more to the top and taper; (3) with a porch in front or beside the main hall of the mosque; (4) a pool in front or side of the mosque; and (5) one, two or three gates in the vicinity of the mosque by the wall. There are several factors of ancient mosques that have specificity [2]: first, in terms 


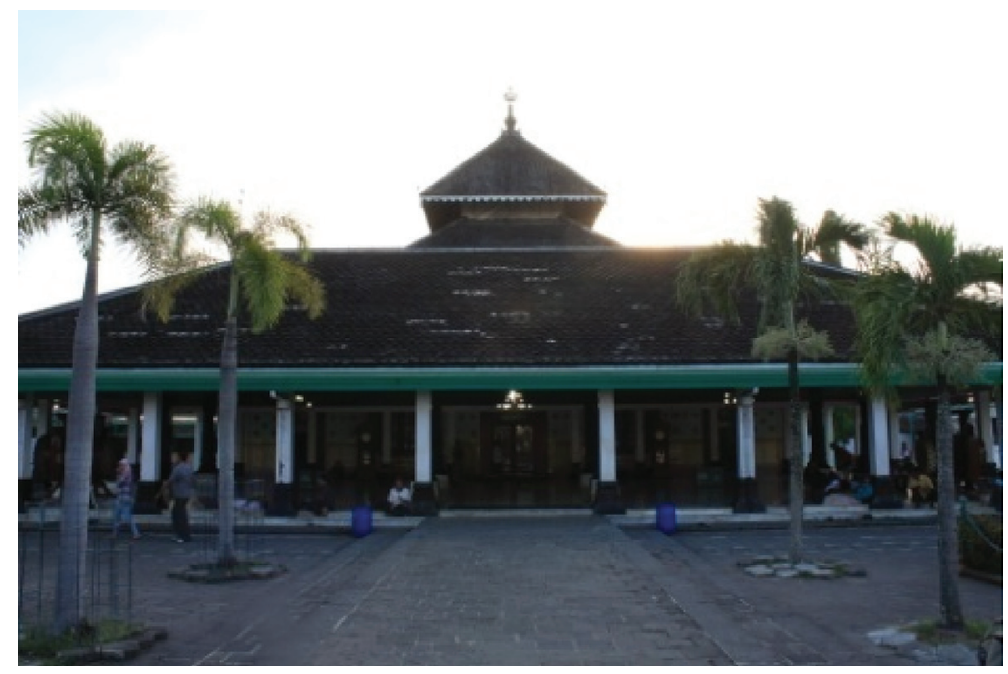

Figure 1: Demak Great Mosque.

of techniques adapted to the ecology; second, in relation to the form that takes the pre-Islamic era to cause an attraction for those who made the transition from Buddhist Hinduism to Islam. According to Hasan Muarif Ambary [3], at that time, design of the mosques, whereby the structure and the construction and layout, adapted to the natural environment and local culture.

Based on the period of the construction of the mosques, according to O'Neill [4], the mosques in Southeast Asia, particularly in Indonesia, can be grouped into categories: the mosques built in 16th century, 17th century, 18th century, and 19th and 20th centuries. Meanwhile, Wirjosuparto [5], based on their types, grouped mosques in Indonesia into four types, namely: (1) mosques used for Friday prayers, called jami (grand); (2) mosques used only for the five daily prayers, and not for Friday prayers, called musahala, langgar, tajug, meunasah, and others; (3) monumental mosques; and (4) mosques with tombs inside (commonly called Mashhad).

Based on these categorizations, the mosques which are the focus of this study are the Great Mosques (Masjid Agung). The name Masjid Agung generally refers to the ancient mosques, which are located in the centres of imperial characters of Islam in Java, such as in Banten, Cirebon, Yogyakarta, Kartasura, Sumenep and others. Meanwhile, in Sumatra, large mosques, called Masjid Raya, are located in the royal centres such as in Aceh, Medan and other cities. Both the Great Mosques and Masjid Raya are usually the mosques, which mean the places of worship performed by sultans, their families and the people located near the palaces. Therefore, Nasution [6] calls such mosques as Masjid Sultan (Mosques of Sultans), while Nasir [7] names these mosques as empire mosques (masjid kesultanan). This paper uses the term Masjid Sultan built in connection with the Islamic kingdom, and such mosques are usually located near the palace and the main square.

According to Rochim [8], generally, the common shape of the royal mosque architecture is determined by the power of the sultans of Islam who have magnificent wealth, and powerful and authoritative facts. One interesting problem to be studied in this research is the subject form of kingdom mosques in Indonesia according to various experts, such as Aboebakar [9], Fanani [10, 11], MichellGeorge [12], Brown [13], Graaf [14], Frishmandan and Khan [15], 
and Grabar [16], showing different complexions of mosques in Islamic countries originally from the Arab and other Muslim countries such as India, Persia and the Middle East. The mosques in Indonesia illustrate different characteristics as unique identities with those outside Indonesia. In the global context, the mosques in Indonesia have the characteristics of different localities compared with general mosques within the Islamic world outside Indonesia. In the context of architecture, royal mosques have elements derived from local culture and foreign cultures, and elements of Islam itself. Mosques can be seen also as an arena or space that shows the influence of Islam tug of war between global and local culture embodied in the various manifestations of material objects that exist in the mosques.

The study of this royal mosque type may disclose the typical patterns of different Indonesian mosques from those outside Indonesia, as well as displaying forms of Islamic influence and compromise the Islamic and local cultures of the mosques and the role of the sultan in the underlying factors.

\section{CHARACTERISTICS OF ROYAL MOSQUES IN INDONESIA}

The meaning of royal mosques in this paper is taken from Ref. [17], which states that these types of mosques are founded by the king as a symbol of power of Islamic kings near the kingdom palace with the ownership signs of Islamic kings inside the mosques.

Based on the study of a number of royal mosques in Indonesia done by Nasution [17], which include the Great Mosque of Demak (Demak), Great Mosque of Sang Cipta Rasa Cirebon (Cirebon), the Great Mosque of Banten (Banten), the Great Mosque of Mataram (Kotagede), Old Mosque Katangka (Gowa), Old Mosque Palopo (Luwu), Old Mosque Ternate (Ternate), the Great Mosque of Surakarta (Solo), Masjid Agung Yogyakarta (Yogyakarta), Masjid Jamik Sumenep (Madura), Masjid Jamik Pontianak Sultanate (Pontianak), Masjid Raya Al-Osmani (Medan), Masjid Jamik Ismaili (Deli Serdang), Azizi mosque (Tanjung Pura), and Al Mashun (Medan), the shape and style of the royal mosques and characteristics that distinguish these types of mosques from the mosques for public are described (Fig. 2).

The characteristics of the kingdom mosque are as follows. It has a porch or tratag in front of the mosque or in the east of the mosque, which is special to be passed by the sultan; there is

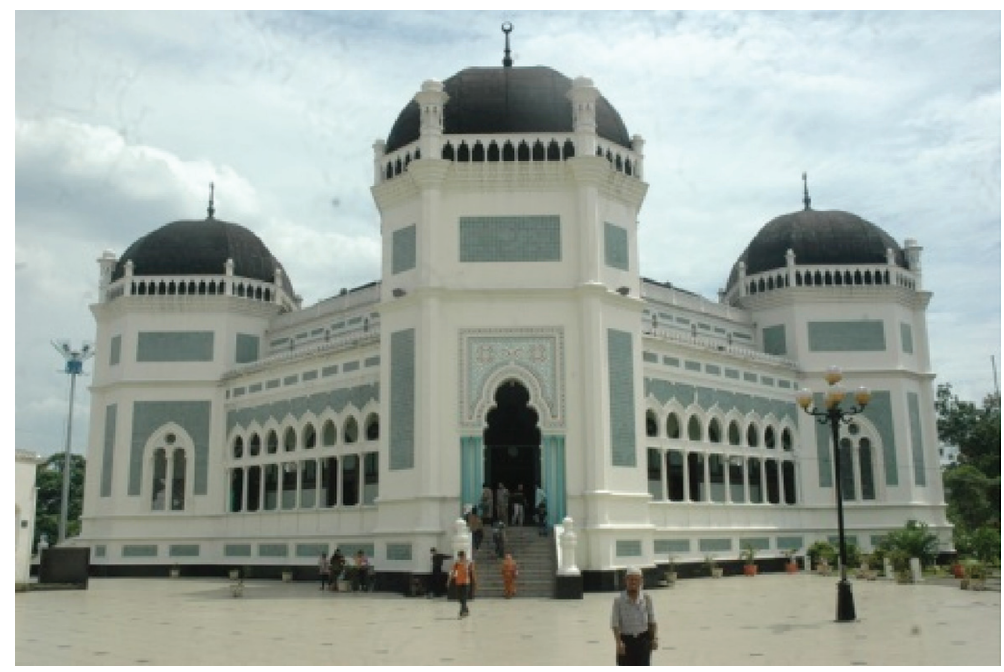

Figure 2: Masjid Raya Al Mashun Medan. 


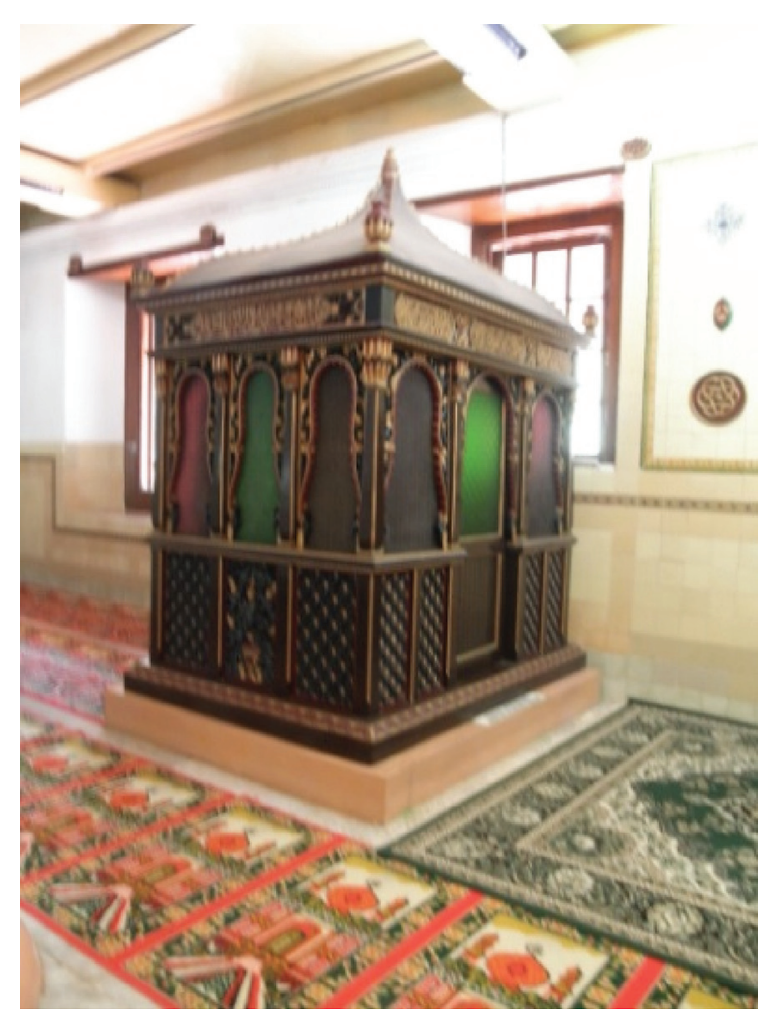

Figure 3: Maksurah of Royal Mosque, Demak.

a main door which is crossed and be crossed by the sultan or king and his entourage escorted; there is maksurah room standing near the mihrab, where the sultan prays sincerely in the mosque, with overlapping roofs numbering three or more with decorative mamolo at its peak; the pulpit which is the throne adorned with decorative botanical form of tendrils and special motives, ornate arches of mosque mihrab and other special motifs or ornaments in the main hall with a pole pillar of the large support to the roof of the mosque and reinforcing pillars and other smaller sizes, symbols or inscriptions as a marker of the mosque belonging to the palace, a tower, a special artefact that shows a mosque belonging to the palace, as symbols of the palace, the original Koran of their time, the flag, the orchestra, drum, istiwa, umbrellas and so on (Fig. 3).

\section{BEING OF POWER REPRESENTATION}

The form of representation of the power of the sultan to the mosque can be traced from the relationship between the palace and the mosque, especially on the material culture that includes the shape of the building, layout, decoration and shape of the practice of ritual conducted in the mosque. In terms of the shape of the building, power relations are visible manifestation of their similarity to the palace buildings in the form of a building in the mosque. In other words, the power relation of royal palace to the mosque can be traced through the architectural forms that appear on both buildings. For example, in Java, the shape of the roof of the palace of Yogyakarta, Surakarta and Cirebon using Java traditional roof is a pyramid 
with joglo roof. Generally, religious buildings in Java also use traditional Java roof shape like the pyramid shape and tajug. In Sumatra, the architectural form of Maimun Palace has architectural forms of India and the Middle East and this is similar to the shape of Masjid al Mashun. The same thing is also found in mosques in Kalimantan, Sulawesi and Ternate, which has a tendency to form the shape of the mosque palace architecture. This shows that the power of the palace to the mosque appears on a form of matter that has a similarity in architectural form as in the style of the roof showing the traditional style or the style of foreign influence (Figs. 4 and 5).

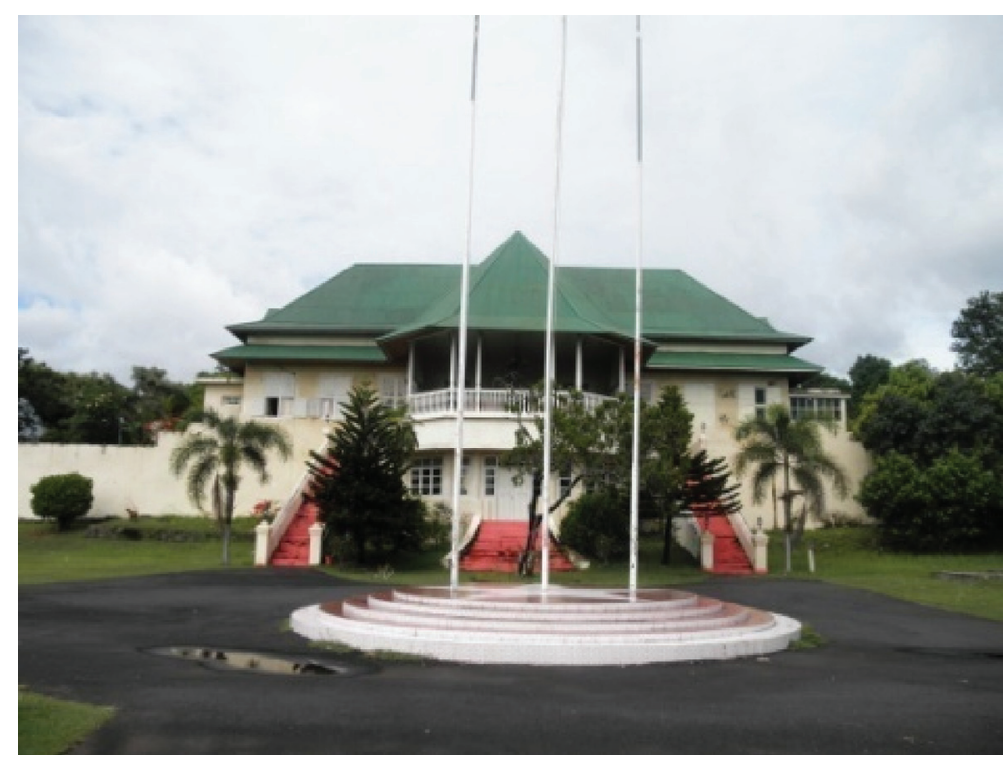

Figure 4: Kedaton Ternate.

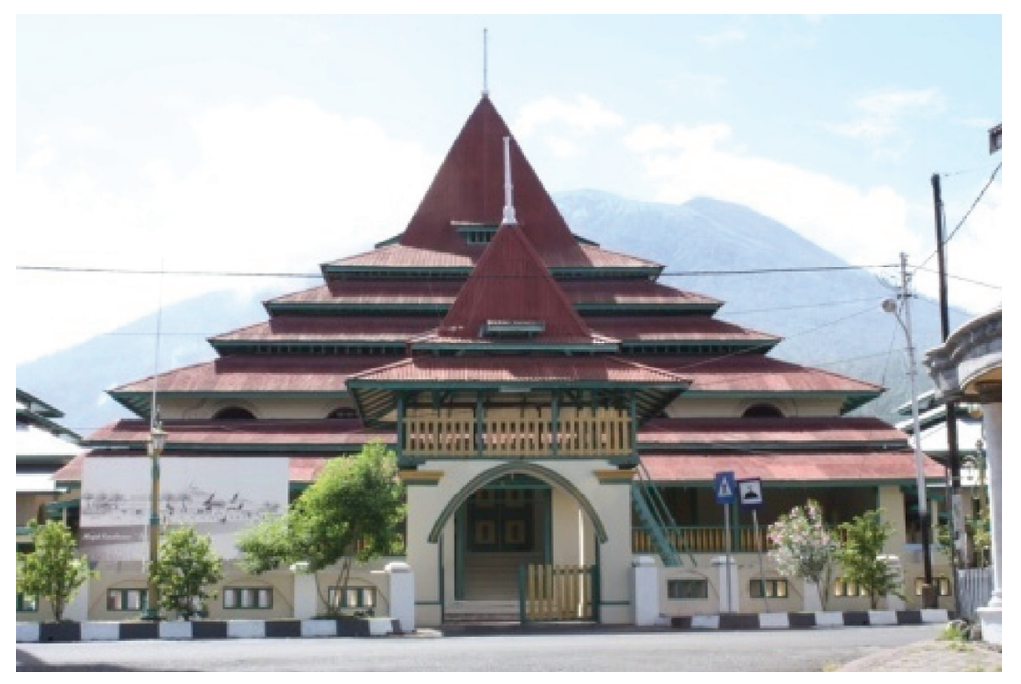

Figure 5: Masjid Tua Ternate. 
In addition, the form of representation of power can also be demonstrated by the form of the decoration. For example, the decoration on the Great Mosque of Cirebon shows similarities with the decoration on Kasepuhan Palace (the royal palace of Cirebon Kingdom). The lotus flower motifs which located on the pole head and on the side of the Mihrab in the Great Mosque of Cirebon have resemblance characteristic with the motif decoration in Kasepuhan Palace. Ornaments in Medan Maimun Palace have the same shape with decoration in Masjid al Mashun Medan, with the decorative motif of tendrils and geometric shapes. There are many more similar architectural forms and ornaments in the mosque with architectural forms and ornaments on its palace, which can indicate the mosque into a representation of the power of the sultan. From its layout, proximity with palaces in some places illustrates the power relation and strategies of sultanate mosques in Islam when Islam came to the area with some considerations in regard to locality.

The representation of power of the mosque can also be found on the rules applied in the mosque. This is in line with the opinion of Foucault [18] regarding power that the application of that power can be traced from the existence of rules and normalization. The rules in the mosque concerning worship are generally applicable to regulations based on the Quran and Hadith. The rules generally are accepted in the mosque and are followed by all the pilgrims to offer prayers in the mosque, without the exception of a king. In the context of the royal mosque, there are special rules that are applied in the royal mosque, combined with rules generally accepted in the mosque. Rules are rules that apply to mosques empire can be traced through written sources and oral sources, which outline that the rules of the past are still valid today. Among them are the prayers, especially the Friday prayer, which can be started when the sultan or king arrives in the mosque. Besides, kingdom mosques have specific rules compared to other mosques, for example, the implementation of the call to prayer is done before Friday prayers begin, regardless of done by a muezzin, but carried out by more than one muеzzin. Among them are: (1) Adzan (prayer call) is headed to Pitu in the Great Mosque Cirebon, (2) the Adzan of five people at Masjid al Mashun, (3) Adzan with four people in Ternate mosque and others.

Besides that, in mosques ceremonies like sekaten, grebeg maulud, long talisman are often performed and others are conducted in the palace, and the mosque is also involved to show the relation of sultan's power at mosques in the past which is still preserved and performed annually in mosques near the palace or centres of power as a representation of the power of the sultan in ritual practice.

\section{ROYAL MOSQUE AS THE IDENTITY AND RESISTANCE}

Based on the study of royal mosques in several places in Indonesia, we can obtain a description of the general pattern of mosques, namely the shape of a cube or rectangular beam by a roof. It can be traced back to the Great Mosque of Cirebon, whose roof does not stick to the walls of the mosque, but on the wall. Therefore, it looks more as mosque walls that surround the space of four terms as well as in Arab mosques with hypostyle pattern. For that reason, the shapes of the building cubes of several mosques in Indonesia seem to mimic the shape of the $\mathrm{Ka}$ 'ba in Mecca as building cubes. The forms showing the impersonation can be traced from the mosque plans in Indonesia, which are likely to be rectangular or square bounded by walls with a number of doors or windows on each side with symmetrical shapes or the same except on the east side. The mosques in the Arab world tend to be rectangular and in the form of an open space without a roof as in Indonesia. The mosques in Indonesia, due to climatic factors, need a roof to protect themselves from sun and rain.

The existence of the roof at each mosque can be generally grouped into two groups: tajug pyramidal roof and pyramidal roof, with the number of three overlapping roofs to became 
the main feature of the earlier mosque building empire that complements the shape of the building cubes or blocks. The existence of this roof adopts local elements into the Islamic architecture of mosques in Indonesia. The second group is located on the domed roof of the mosque al Mashun, Jamik Ismaili mosque and the mosque of Usmaniyah in Sumatra. In general, domed roof mosques have also been influenced from outside Indonesia, India or Persia. If you pay attention to the context of time, generally overlap roofed mosque is a mosque from the 16th and 17th centuries $\mathrm{AD}$ to 18 th century $\mathrm{AD}$, while the dome-roofed mosque usually originates from the 19th century and early 20th century at the beginning of Islam. Based on the study of the shape of the roof of the mosque, Sumalyo [19] states that the general shape of the domed roof at the mosque is originally from Persia, India, Egypt and Saudi. However, archaeological evidence and the source of the oldest board show the earliest roof of the mosque is tajug pyramidal roof instead of a domed roof. This shows that the propagator of Islam at that time was to build the mosques tailored to local cultural society dominated by the traditional architectural style of building timber and also the influence of the rulers. This is in line with the opinion of Rochym [8] that since the beginning of its development, Islam has to be open to the elements as the traditional cultural aspect which later became a strong foundation for development. Therefore, the traditional architecture of the area can support the appearance of a mosque with traditional regional elements such as shapes evolved since its early growth. In the next period, the mosques undergo a process of repair and expansion by adding new spaces around the mosque, as well as the material was changed from wood to materials that are more solid as it looks now. The influence of western colonial culture or prominent architect in the mosques of the 19th century and 20th century AD were built by European architects. The dominance of the domed roofs shift overlaps, even though the roof of the mosque on some ancient mosques are still built as a form of resistance.

The study of the mosque components such as mihrab, minbar, maksurah, pawestren, porches, arches, pillars and others to show the presence of elements of pre-Islamic culture (HinduBuddhist) continues with the elements of local culture. Both elements are reflected through the complexion of mosque building and the decoration. The style buildings showing the influence of the pre-Islamic cultural element is the shape of the roof of the mosque tiered or three overlapping roof. Elements of local culture can be seen from the mosque roof construction using high roof pattern as in traditional houses in Nusantara. The decoration that depicts the influence of the pre-Islamic cultural elements and local cultural elements is shown in the presence of motifs such as lotus, sulur-ropes, lozenges, fried flower decoration, mirror frame motifs, geometric motifs, meanders, chains and parts of the mosque in the kingdom as the mihrab and minbar.

Apart from the local elements, the presence of foreign cultural elements, including the use of Arabic letters in the inscription printed on the wall of the mosque, the use of tile terrazzo on the floor of the mosque, the use of force foreign construction (India, Egypt and Arab) on roofs, towers, arches, window, doors, dikba and also maksurah, is found. The shape of Surakarta Grand Mosque tower illustrates the shape of the tower of Qutub Minar in New Delhi, India, as al-Mashun minarets, towers of Jamik Ismaili mosque and minaret Azizi in Sumatra. Maqsurah influx into the mosque in the archipelago shows the influence of foreign cultural elements functioning as a new identity on a mosque that indicates the mosque is the one belonging to the empire. Maqsurah is found in kingdom mosques like Great Mosque of Cirebon, Yogyakarta Masjid, the Grand Mosque of Surakarta, Jamik Sumenep Mosque and Masjid Kedaton Ternate. Maqsurah existence in the mosque is an Islamic sultan's new effort towards cultural products that come in line with the interests of the sultan to strengthen his power in the mosque. Maqsurah is the representation of the power of the sultan in the mosque. 
The meaning contained in the mosque architecture also shows Islam's incorporation of cultural meanings of local and mixing it with the implied meaning within Islam itself, so that the local people can see a mix of material cultures in the various components of the mosque and meaning to the idea that these are given the breath of Islam to Islamization strategies to attract people who are not against Islam through the building and decorative arts.

The mosque in the capital of the kingdom is also a symbol of Islamic identity of the kingdom and it is strengthened with Maqsurah in it. The building style and completeness of its components show a typical pattern of the royal mosque, which distinguishes it from the public mosque. Mosques are sacred places in which are the interests of the power of the sultan in displaying its power through all the material culture such as the existence of maqsurah, the presence of the tower, roof-style mosque with its mustoko, pulpit and mihrab, porch and pawestren, the main gate and the door of the mosque, and drum and other Islamic artefacts. Sultan's power is manifested in almost all products of material culture in the mosque with best quality in terms of shape, material and size.

Royal mosques in Indonesia have typical building styles and are different from the other Islamic mosques in the world. This difference can be seen as the identity of the Indonesian mosques with different shades and in the Islamic world as a strategy to counter the influence of the global Islamic culture of the time. Then a mixture of cultural elements in mosques as a form of compromise with the local Islamic global Islam came into existence. The foreign cultural elements from outside of Islam adopted into the mosque do not affect all creeds and worship in the mosque.

The presence of Islam in Indonesia, which is evident from the existence of the mosque in the archipelago, shows that cultural diversity strategy illustrates Indonesia in the face of influences that come and surge into the archipelago. Nonetheless, normative Islamic community in Indonesia vary in line with the context of understanding and the lessons learned, without leaving the main Aqeedah of Islam as monotheism.

\section{CONCLUSION}

The finding of this study is the royal mosque as a kind of mosque that has a special shape, and signs as belonging to the kingdom as a place where prayer is performed by sultan, that is maqsurah. Inside the mosque, there are a number of components of the building that show the power of the sultan with specific rules. Usually the shape of the mosque has a relationship with the shape of the palace, and under the power of sultan marked by its location near the main square and the palace, and close to the major buildings such as the tombs of the Sultan and his relatives, negotiating room and settlement of the elite and clergy.

The mosque became sultan's Islamic identity and empire through its location, building styles and rituals accompanying the mosque. The identity of the royal mosque is illustrated by the majesty of overlapping roof shapes in the early days of Islam until the mid-19th century $\mathrm{AD}$, and then proceeded with the shape of a domed roof. Grand mosques in the capitals of the kingdoms represent the power of Islamic sultan at the district level followed by the mosques using overlapping roof and a symbol of feudal power as a tool of colonial rule in these areas. Mosque's domed roof appears to take over overlapping roof as a representation of the power of new Islamic sultan who choses the dome as the identity of the new Islamic mosques under the influence of the Islamic countries in that era. Nonetheless, the characteristics of archipelago mosques remain present to distinguish it from outside a mosque in Indonesia as described as a strategy of the sovereign power of the archipelago facing a wave of global Islamic influence into Indonesia. Mosques have become the sovereign power through the content representations of material culture's grand appearance. 


\section{REFERENCES}

[1] Tjandrasasmita, U., Masjid-masjid di Indonesia. Nafas Islam Kebudayaan Indonesia. ed. Munawir Sjadzali \& H.B. Jassin, Festival Istiqlal: Jakarta, p. 49-51, 1991.

[2] Tjandrasasmita, U., Arkeologi Islam Nusantara, KPG: Jakarta, 2009.

[3] Ambary, H.M., Menemukan Peradaban Arkeologi Islam di Indonesia. Puslitbang Arkenas: Jakarta, 1998.

[4] O'Neill, H., South East Asia. The Mosque. History, Architectural Development and Regional Diversity. ed. M. Frishman \& Hasan-Uddin Khan, Thames and Hudson: London, pp. 225-240,1994.

[5] Wirjosuparto, S., Sejarah pertumbuhan masjid Indonesia, Majalah Fajar, 21, pp. 7-8, 1961.

[6] Nasution, I.P., Masjid Keraton di Indonesia:representasi dan kekuasaan, Laporan Penelitian, Direktorat Riset dan Pengabdian pada Masyarakat Universitas Indonesia, 2010.

[7] Nasir, A.H., Seni bina masjid di dunia Melayu-Nusantara, Universiti Kebangsaan Malaysia: Bangi, 1995.

[8] Rochym, A., Masjid dalam karya arsitektur nasional Indonesia, Angkasa: Bandung, 1983.

[9] Aboebakar, Sedjarah masjid dan amal ibadah di dalamnya, Toko Buku Adil: Bandjarmasin, 1955.

[10] Fanani, A., Arsitektur Masjid: Perkembangan Pemahaman Islam, Ruh Islam Dalam Budaya Bangsa: Konsep Estetika, Yayasan Festival Istiqlal, pp. 94-102, 1996.

[11] Fanani, A., Arsitektur Masjid, Bentang: Yogyakarta, 2009.

[12] Michell, G., ed., Architecture of the Islamic World: Its History and Social Meaning, Thames and Hudson: London, 1978.

[13] Brown, P., Indian Architecture (The Islamic Period), D.B. Taraporevala Sons \& Co. LTD.: Bombay, 1942.

[14] Graff, H.J. de., The origin of Javanese mosque. Journal of Southeast Asian History, 5, pp. 1-5, 1963.

[15] Frishman, M. \& Khan, H.U., The Mosque: History, Architectural Development \& Regional Diversity, Thames and Hudson: London, 1994.

[16] Grabar, O., Islamic archaeology: An introduction. Historical Archaeology: A Guide to Substantive and Theoretical Contribution, ed. Robert L. Schulyer, Baywood Publishing Company, Inc.: New York, pp. 57-60, 1978.

[17] Nasution, I.P., Masjid Kerajaan di Indonesia Abad 16-20 Masehi sebagai Representasi Kuasa, Disertasi, Depok: Fakultas Ilmu Pengetahuan Budaya Universitas Indonesia, 2014.

[18] Foucault, M., Wacana Kuasa/Pengetahuan, trans, Y. Santosa, Bentang Budaya: Yogyakarta, 2002.

[19] Sumalyo, Y., Arsitektur masjid dan monumen sejarah muslim. Gadjah Mada University Press: Yogyakarta, 2000. 